\title{
Sustainability of Islamic Microfinance Institutions through Community Development
}

\author{
Rashidah Abdul Rahman ${ }^{1,3}$, Ahnaf Al Smady² \& Soheil Kazemian ${ }^{3}$ \\ ${ }^{1}$ Accounting Department, Faculty of Economics and Administration, King Abdulaziz University, Saudi Arabia \\ ${ }^{2}$ Accounting Department, Faculty of Economics \& Administrative Sciences, Applied Science Private University, \\ Jordan \\ ${ }^{3}$ Accounting Research Institute, UniversitiTeknologi MARA, Malaysia \\ Correspondence: Rashidah Abdul Rahman, Accounting Department, Faculty of Economics \& Administration, \\ King Abdulaziz University, Jeddah, Saudi Arabia. Tel: 966-543-126-672. E-mail:rabdulwahid@kau.edu.sa
}

Received: March 31, 2015

Accepted: April 29, 2015

Online Published: May 25, 2015

doi:10.5539/ibr.v8n6p196

URL: http://dx.doi.org/10.5539/ibr.v8n6p196

\begin{abstract}
Although conventional microfinance products have been very successful in Muslim majority countries like that of the notable Grameen Bank in Bangladesh, the traditional microfinance contract which involves the payment of interest is strictly prohibited with the principles set forth in the Shariah of Islam. Hence, the Islamic microfinance proponents have taken the initiatives to meet the increasing needs of the Muslim clients with the aim of alleviating poverty and to help the poor people in distress. While conventional microfinance institutions (MFIs) have expanded their operations in the last two decades, the dearth of Islamic MFIs is a glaring absence in the industry. Government and private donor funds alone are not sufficient to fill in the extremely large gap between the supply and demand of Islamic microfinance services. At the micro and institutional levels, government and private donor funds can play a major role to finance start-up costs, training and development of staff and exposure to best practices for new and growing Islamic MFIs. The gap can only be filled through a substantial increase in self-sustaining profitable microfinance institutions and by establishing the Islamic Microfinance Community (IMC). Thus, this paper critically examines the development of Islamic MFIs, particularly in Malaysia and maps out suggestions to overcome the barriers to being self-sustaining by establishing Islamic Microfinance Community (IMC). The implementation of the authentic model of Islamic Microfinance Community in Malaysia and other parts of the world can ensure the proactive development and efficient running of micro financing, so that self-sustaining and human-centered development, enhancing of social capital and spiritual well-being, aimed at helping the poor individuals and entrepreneurs who are excluded from economic and financial activities, can be achieved.
\end{abstract}

Keywords: Islamic microfinance, poverty reduction, sustainability

\section{Introduction}

Microfinance (MF), a supply of relatively small loans and other basic financial services such as savings facilities, training, health services, networking and peer support to the poor or those who do not have access to typical banking services, has made a difference in the lives of many over the years across the globe (Microcredit Summit, 2013). This program is introduced as commercial loans were not designed to help individuals who do not have financial assets, where most financial institutions takes into consideration the perceived high risks, high costs involving small transactions, and also the inability of the poor in providing marketable collateral (Asian Development Bank, 2013; Kiva, 2013). Drifting away from limits being imposed by neo-classical thought, this new wave makes an implication towards new responsibilities to an organisation, which falls under the rubric of corporate social responsibility (Ferro, 2005). Being different to commercial loans, microfinance does not require any collateral or guarantor, which is based on trust, and is usually repaid within a timeframe of six months to a year, where these funds are then recycled to keep the money working in the hands of borrowers (Grameen Foundation, 2013). These loans are also given with a compulsory saving package or voluntary saving, where its priority is to establish social capital through group joint projects that are established among the loan recipients. The Microfinance programme has been proven to have been successful over the years, in many countries to address problems of income inequalities and poverty, having been recognised by the World Bank with 2005 
being declared as the year of microfinance as a part of their poverty reduction campaign (Abdul Rahman, 2007). Through microfinance, the poor can enjoy greater self-sufficiency and sustainability, granting them innate entrepreneurial abilities that can generate jobs, income and wealth.

Despite its success, conventional MF has been criticised from an Islamic perspective as some people view conventional products offered by MF institutions as incompatible with the financial principles set forth in Islamic law. As argued by Karim, Tarazi, and Reille (2008), surveys in Jordan, Algeria and Syria revealed that 20-40 percent of respondents cite religious reasons for not accessing conventional microfinance - leading to the emergence of Islamic microfinance (IMF) as a new market niche. Islamic microfinance represents the confluence of two rapidly growing industries: microfinance and Islamic finance. The basis of Islamic finance comes from the Islamic regulations (shariah), that is basically prohibiting any form of interest or usury (riba) being involved in business activities or monetary transactions as prescribed in the Quran's Surah Al-Baqarah, in its 275th verse. The verse basically argues that Islam has permitted trading but prohibited riba. This concepts puts emphasis that money does not have intrinsic value, therefore there should be no charge for its usage as money is only a measure of value and does not carry any value to it.

The potential of Islamic microfinance does not only restrict to the need of meeting demands, but also to integrate the Islamic social principle to care for the less fortunate with microfinance's ability in providing financial access to the poor (Karim, Tarazi, \& Reille, 2008). By revealing this potential, millions of Muslim poor would have access to financial aid, where they are currently rejecting microfinance products due to its incompliance to Islamic law. An Islamic model of microfinance would propose a paradigm shift of social enterprise, where profit and loss sharing that is being practiced widely in Islamic finance would replace interest-based financing of the current microfinance practice (Goud, 2007).

In battling poverty and for a sustainable equitable growth, financial inclusion has taken a front seat in various development dialogues across the globe including Malaysia. The goal of financial inclusions in any developing economies is to focus on bringing the unbanked poor into the financial mainstream. Financial inclusion will enable all citizens, including the low-income and poor residents, to have the opportunity to undertake financial transactions, generate income, accumulate assets and protect themselves financially against unexpected adverse events, thereby enabling them to benefit from economic progress. This will, in turn, contribute to balanced and sustainable economic growth and development.

What the underprivileged need is not an exclusive financial system of microcredit subsidised by charitable means, but more importantly to have access to the existing system with a range of financial services that include savings, affordable and convenient ways to transfer their money, more so with the advancement of technology, and various takaful products to insure themselves against vagaries of misfortune such as health or draught, and the know-how of being a financial literate. This is achievable with the establishment of a sustainable (self-dependent and self-sufficient) Islamic Microfinance community. By having a community that is inclusive of Islamic microfinance providers; participating merchants; zakat and waqf institutions; also utilities providers; the recipients would be encouraged towards being financially stable and self-sufficient to support themselves and their families and be part of the financial mainstream.

The objective of this paper is to highlight the need for an Islamic Microfinance Community, both as part of a social, economic and spiritual mission, out of recognition that poor people represent a vast and potentially lucrative untapped financial market. The next section highlights the need for an Islamic Microfinance, followed by a discussion on the development of Islamic Microfinance in Malaysia in Section 3. Section 4 introduces the proposed Islamic Microfinance Community while Section 5 concludes and suggests a way forward for the Islamic Microfinance industry.

\section{The Need for Islamic Microfinance}

Honohan (2008) claimed that an estimated $72 \%$ of people living in Islamic countries cannot access formal financial services. A survey conducted by CGAP in 2007 had revealed that Islamic microfinance had a total estimated outreach of 380,000 clients, which accounts for only 0.5 per cent of the total microfinance outreach. This is where the concentration of Islamic microfinance products is focused in several countries, with Indonesia, Bangladesh and Afghanistan being accounted for 80 per cent of the overall global outreach (Karim, Tarazi, \& Reille, 2008; Karim \& Khaled, 2011). In most Arab countries, microfinance institutions that have been established for 7 to 10 years would normally reach a number of 2,000 to 7,000 clients that actively uses these institutions' Islamic products while in contrast acquiring thousands of active clients for their conventional products. Islamic microfinance was also found to be represented as less than 1 per cent of the global microfinance programmes (Khan, 2011). 
Despite those discouraging numbers, the demand of Islamic microfinance is still going to be high, as findings from most other countries with Muslim-majority, such as Jordan, Algeria, and Syria, showed that 20 to 40 per cent of respondents had mentioned of various religious reasons for not taking up conventional-based microloans. Also, Khan (2011) had provided evidences that 25 to 40 per cent of Muslims decide to stay away from interest-based microfinance products because they fear that they would be breaching their religious beliefs. This number of outreach could only be optimally increased if clients' confidence towards Islamic microfinance institutions are properly developed (Khaled, 2011). This could be achieved if these low-income clients are convinced that Islamic microfinance products are authentically following Shariah jurisdiction. Therefore, Islamic microfinance products are able to offer an alternative path to millions of poor individuals who are currently declined from being served by conventional microfinance (Karim \& Khaled, 2011). This small industry should not only adopt innovation into their operations, but also prove that the models they are introducing would actually work to provide sustainable service on larger scale. This means deeper market research and more comprehensive initiatives should be attempted to complement the capacity of players on various levels in the industry.

\section{Development of Islamic Microfinance in Malaysia}

With a population of more than 28 million of which $60 \%$ are Muslims, Malaysia provides a large consumer market potential for micro-entrepreneurial development. In a keynote address at the Global Donors Forum 2012, the Prime Minister of Malaysia, Datuk Seri Najib Tun Razak had also expressed the need for establishing Islamic microfinance as a new market niche (Bernama, 2012). According to the Prime Minister, Islamic microfinance does not only represent an opportunity of developing ethical yet profitable products, but also supporting social entrepreneurial activities and investing in social funds over the long-term.

As shown in Table 1, microfinance providers take four distinct forms namely microfinance institutions, cooperatives (credit unions), development financial institutions and commercial banks with microfinance schemes (Global Islamic Finance Report, GIFR 2012). The three main microfinance institutions are Amanah Ikhtiar Malaysia (AIM), Yayasan Usaha Maju (YUM) and Economic Fund for National Entrepreneurs Group (TEKUN).

Replicating the prominent Grameen Bank model, AIM was introduced in Malaysia under the name of "Project Ikhtiar" (Mokhtar, Nartea, \& Gan, 2010). This project commenced in 1981 by two social scientists from Universiti Sains Malaysia, Dr David Gibbons and Professor Sukor Kasim under the Trustee Incorporation Act 258 (revised 1981) (Chamhuri \& Quinones, 2000). This initiative had shown to be a success, and proved that the group lending system introduced by Grameen Bank is applicable in the environment of Malaysia. Based on pilot study, the project managed to meet its initial target, which was to reduce the poverty level among the poorest households in the poorest agricultural block. The project was subsequently restructured in 1987 as a non-government organisation to become Amanah Ikhtiar Malaysia (AIM), the largest Grameen Bank replication outside Bangladesh and leading microfinance institution in Malaysia (McGuire, Conroy, \& Thapa, 1998; Mokhtar, Nartea, \& Gan, 2010).

The second adaptation of Grameen Bank was done in Sabah, by the establishment of "Project Usaha Maju" by the Grameen Trust Fund and Rural Development Corporation in 1988 (Chamhuri \& Quinones, 2000). Looking at the achievement of Project Usaha Maju in taking its members out of poverty, the Sabah state government decided to institutionalise Project Usaha Maju, forming Yayasan Usaha Maju (YUM) on June 30th, 1995 as a registered organisation under the Trustee (Incorporation) ordinance 1951 chapter 148 of Sabah (YUM, 2009; Mokhtar, Nartea, \& Gan, 2010). The lending system of YUM is similar to its Peninsular Malaysia counterpart, AIM. The only difference is that YUM applies individual lending system rather than doing it in groups, as its borrower's geographical settling is rather diverse, even when they are living in the same village. Hence, the borrowers would not be able to be present in meetings and peer monitoring would not work in such circumstances. 
Table 1. Type of microfinance institutions (MFIs) in Malaysia

\begin{tabular}{|c|c|c|c|c|}
\hline Type of MFI & Example & Ownership & Legal Basis & Fund Source \\
\hline $\begin{array}{l}\text { Development } \\
\text { Financial } \\
\text { Institutions }\end{array}$ & $\begin{array}{l}\text { - Agrobank } \\
\text { - Bank Rakyat } \\
\text { - Bank SimpananNasional }\end{array}$ & $\begin{array}{l}\text { Government } \\
\text { (GLC) }\end{array}$ & $\begin{array}{l}\text { Development Financial } \\
\text { Institutions Act } 2002\end{array}$ & $\begin{array}{l}\text { Government grant, } \\
\text { equity capital, deposits, } \\
\text { commercial funds }\end{array}$ \\
\hline $\begin{array}{l}\text { Banking } \\
\text { Institutions }\end{array}$ & $\begin{array}{l}\text { - Alliance Bank } \\
\text { - AmBank } \\
\text { - CIMB Bank } \\
\text { - Public Bank } \\
\text { - Maybank } \\
\text { - United Overseas Bank } \\
\text { - Bank Muamalat }\end{array}$ & $\begin{array}{l}\text { Private } \\
\text { Shareholder }\end{array}$ & $\begin{array}{l}\text { Banking \& Financial } \\
\text { Institutions Act } 1989\end{array}$ & $\begin{array}{l}\text { Deposits, equity capital, } \\
\text { commercial funds }\end{array}$ \\
\hline $\begin{array}{l}\text { Non-Governme } \\
\text { nt Organizations } \\
(\mathrm{NGO})\end{array}$ & $\begin{array}{l}\text { - } \mathrm{AIM} \\
\text { - YUM (specialized for Sabah) }\end{array}$ & Trustees & $\begin{array}{l}\text { Trustee Incorporation Act } \\
1952 \text { (Amendment 1981), } \\
\text { Trustee (Incorporation) } \\
\text { Ordinance } 1951\end{array}$ & $\begin{array}{l}\text { Government grant, soft } \\
\text { loans, and commercial } \\
\text { activities }\end{array}$ \\
\hline $\begin{array}{l}\text { Government } \\
\text { Agencies }\end{array}$ & $\begin{array}{l}\text { - TEKUN Nasional } \\
\text { - Council of Trust to the } \\
\text { Bumiputra (MARA) } \\
\text { - Farmers Organization Authority } \\
\text { (FOA) } \\
\text { - Federal Land Development } \\
\text { Authority (FELDA) } \\
\text { - PermodalanUsahawanNasional } \\
\text { Berhad (PUNB) }\end{array}$ & Government & $\begin{array}{l}\text { Parliament Act 1966, } \\
\text { Companies Act } 1965\end{array}$ & $\begin{array}{lr}\text { Government grant, } \\
\text { multilateral institutions, } \\
\text { and } & \text { commercial } \\
\text { activities } & \end{array}$ \\
\hline Credit Unions & KoperasiKredit Rakyat & $\begin{array}{l}\text { Individual } \\
\text { Members }\end{array}$ & Societies Act 1966 & $\begin{array}{l}\text { Share subscriptions and } \\
\text { deposits from members }\end{array}$ \\
\hline
\end{tabular}

Source: Asian Productivity Organization, 2006; Bank Negara Malaysia, 2012.

Another microfinance institution in Malaysia is the Economic Fund for National Entrepreneurs Group (TEKUN), established on 9 November 1998 under the Ministry of Agriculture and Agro-based Industry Malaysia (Mokhtar, Nartea, \& Gan, 2010). The main objective of this institution is to provide easy and fast loans to Bumiputra and Indian entrepreneurs, regardless of being poor or not so poor. TEKUN's services had expanded since 2008 in providing business opportunities and business skills training to its borrowers, also developing network among these innovative-driven entrepreneurs nationwide.

Other than standalone microfinance institutions, several development financial institutions had also participated in supporting the growth of micro enterprises by the improvement of access to formal financial system for these entrepreneurs, in terms of assisting their working capital and capital expenditure (Global Islamic Finance Report, 2012). These institutions had been offering microfinance loans that ranges from RM 500 up to RM 50,000 since 2006 for business financing purposes. Development institutions that are mandated by the government in providing micro credit facilities have their own target clients. For example, Bank Rakyat offers Islamic pawn-broking scheme, while Bank Simpanan Nasional targets non-agricultural businesses and Agrobank concentrates on agriculture and agro-based activities.

Based on the recent development of the microfinance industry in Malaysia, in 2007, the Central Bank of Malaysia (Bank Negara Malaysia) gave the mandate to commercial banks in Malaysia to offer microfinancing. The participating commercial banks include Alliance Bank, AMBANK, CIMB Bank, EONCAP Islamic Bank, Maybank, Public Bank and United Overseas Bank Berhad (Bank Negara Malaysia, 2012). The size of the microcredit given by these banking institutions ranges between RM1,000 (USD300) to RM50,000 (USD15,800) 
without any collateral.

In the Malaysian context, microfinance products being offered in this country are already Shariah compliant, given the concepts of Qard Hassan (benevolent loan) and BaiAl-Inah being practiced by AIM, and other participating financial institutions, respectively (MicroCapital.org, 2009). Another alternative Islamic Financing mode is Ar-Rahnu (pawning) adopted by Bank Rakyat, Agrobank, Bank Islam, YAPEIM, RHB Islamic and Bank Muamalat Malaysia. Ar-Rahnu is based on the concept of Qadr Hassan, Al-ujra (the fee for safekeeping) and WadiaYadhomana (safekeeping with guarantee). In 2007, Bank Islam had started to offer Islamic microfinance schemes to its members by the methodology of Bai Al-Inah to complement its Ar-Rahnu facilities, which had shown an average yearly growth of 20 per cent (Global Islamic Financial Report, 2012). This is where the Ar-Rahnu facilities registered a total of USD 373.13 million in financing and USD 31.99 in deposits with only 6 outlets being set up under the supervision of Bank Negara Malaysia. Bank Rakyat had also adopted the methodology of self-help groups as practiced by Grameen Bank and AIM in its Islamic microfinance scheme called Micro Financing-i Scheme, launched early 2013 (Bernama, 2013). The scheme offers two products of Micro Financing-iMUsK and Micro Financing-i MPPK (Bank Rakyat, 2013). Micro Financing-iMUsK offers direct financing to all cooperative members of Bank Rakyat, while Micro Financing-i MPPK is a collaboration of the bank with the government through KPDNKK as efforts to support small-scaled businesses expand their operation.

The two largest Islamic microfinance institutions in Malaysia, being AIM and Bank Rakyat, have shown tremendous development over the years that had encouraged more government initiatives to be developed in recognising the financial needs of Muslim poor who are in need to financial access that would not jeopardize their religious beliefs towards the prohibition of interest (Global Islamic Finance Report, 2012). Several initiatives that have been initiated by the government in developing the sector of Islamic microfinance and increasing its market outreach were also announced in the Budget of 2012 (Global Islamic Finance Report, 2012). This is where TEKUN had received an allocation of RM300 million as compared to RM120 million in 2011, while AIM received RM2.2 billion from the budget. Also, a 100 per cent stamp duty exemption had been granted to loan agreements of up to RM50,000 that are grouped under microfinance schemes in order to reduce cost of doing business to these microenterprises. Towards this end, Bank Negara Malaysia had released the Financial Sector Blueprint (2011-2020) to reinforce the government's initiatives for an inclusive financial system including Islamic Financial inclusion and microcredit in Malaysia.

\section{Establishment of an Islamic Microfinance Community}

One of the biggest challenges for the microfinance industry in the past few decades is to balance the requirements of operational and financial sustainability of the micro finance institutions (MFIs), and to provide the microfinance services to the poor. According to Uotila (2005), although empirical studies on the MFIs worldwide show that the program in general has a positive socio-economic impact to their clients, the records on operational or financial sustainability of these MFIs are generally poor. This is mainly due to the fact that these MFIs are working individually. In today's scenario, the recipients of the MFIs in general receive money (in term of loans) and several trainings from the MFIs only.

In order to ensure maximum outreach and expand the industry of Islamic microfinance in adhering to its growing need and demand in the Muslim community, and to be able to realise the goals of an inclusive system, there is a need to establish an association named Islamic Microfinance Community (IMC) in Malaysia and also in other countries with Muslim populations. Being able to be self-sustained, these institutions would hence reduce their dependency towards donor funding, especially from government grants (Kulik \& Molinari, 2004). Being able to be self-sustainable would mean that these organisations would also have the chance to be stronger competitors against the big commercial group of financing service providers, and ensure that microfinance services could be served through a variety of channels, being different in terms of size, target clients, geographical reach, products, also development objectives. 


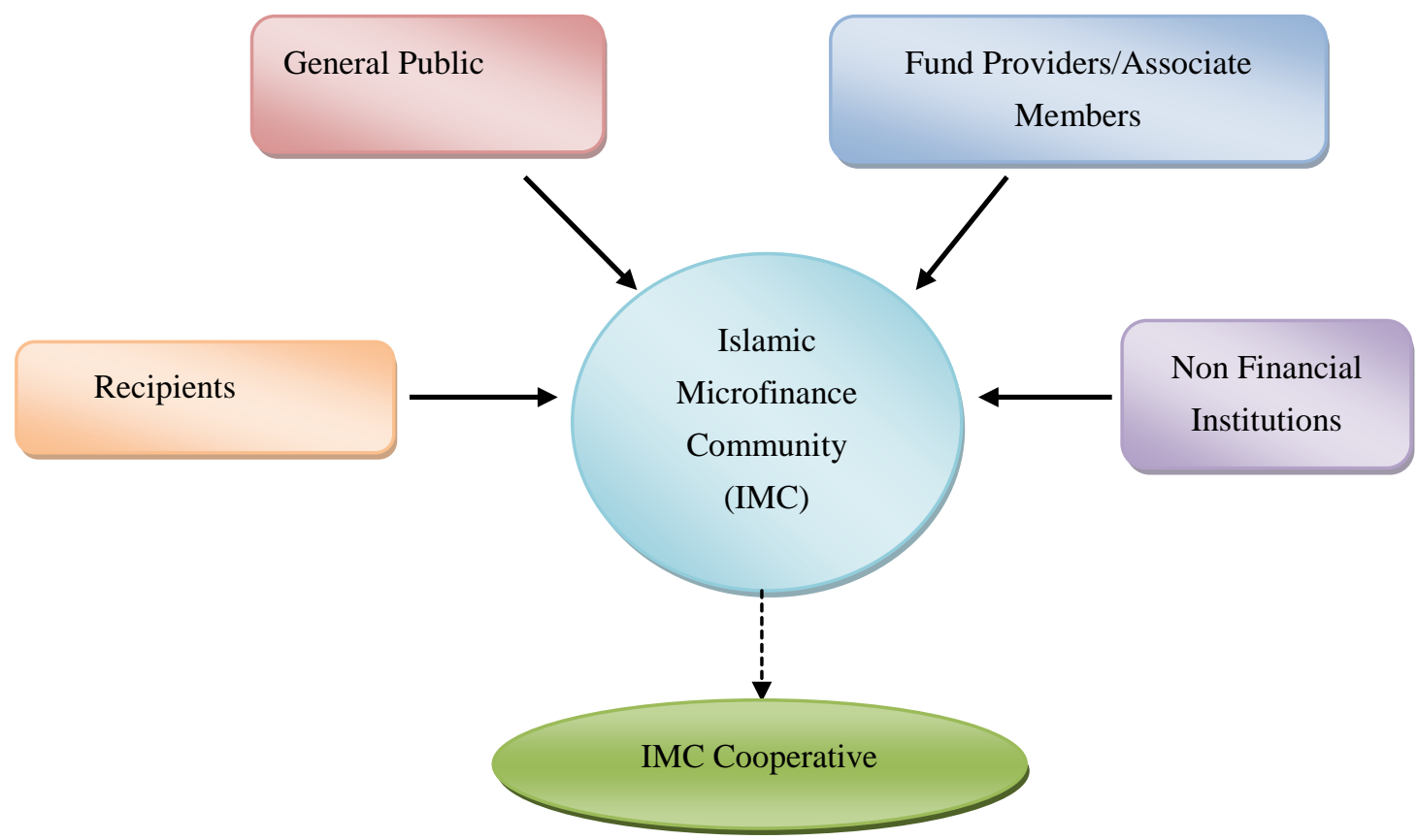

Figure 1. Proposed Islamic Microfinance Community (IMC)

As mentioned earlier, a major problem currently facing the poor is to get access to funding or working capital to begin a business. Inflexible and stringent requirements, and strict rules and regulations imposed by a majority of financial institutions (FIs) in Malaysia, be it conventional or Islamic, limit potential entrepreneurs' ability or opportunities to start a business, penetrate the current and future market or expand their business. FIs would normally offer loans to an entrepreneur with at least a year of good track record in managing their business. Therefore, with the establishment of IMC, the predicaments faced by potential entrepreneurs shall be professionally managed. IMC would provide an easy access to Islamic finance services to the community members. In an Islamic society it is also the responsibility of every member of the community, that is, each one of us, is accountable to ensure social justice and fair distribution of wealth in the society is in place.

Further, it has been argued that the nature of the present microfinance institution's operations puts in more focus towards the 'entrepreneurial poor rather than the variety of financial services required for the poor (Sait \& Lim, 2005). A large body of evidence has shown that poor people need a range of financial services such as safe places to save money, affordable ways to transfer it and the means to insure themselves against the vagaries of misfortune of health crisis or drought. Therefore, there is a need to include savings, takaful coverage and money transfer services to the line of microfinance.

With technology, a proper database of market information within the community can also gather accurate information on IMC perspective clients to facilitate loan approval and disbursement; to avoid competing for the same clients and clients having multiple borrowings and over indebtedness or trapped in a spiralling debt cycle. An accurate database can facilitate the selection of partners (recipients) under the Islamic financial modes such as mudarabah and musharakah, hence reduce the risk of default.

As shown in Figure 1, IMC is a platform whereby members comprising of micro finance recipients could take advantage and gain financially and non-financially. Financial advantage would be in the form of greater access to IMF, reasonable pricing for the purchase or trading of goods among members, saving as well as investment opportunities. Non-financial advantage on the other hand could be in the form of networking, entrepreneurial training, sharing of skills and experiences as well as group support. In becoming a member of IMC, an individual MF recipient or business-inspired graduate needs to pay annual/lifetime membership fee to meet the cost of running the association. Associate members or panels consisting of micro finance providers, commercial banks, development financial institutions (DFI) and Takaful operators are expected to give the recipients greater access to their financial services. Philanthropic institutions such as Lembaga Zakat (Zakat Foundation) and wakaf are expected to give their financial support and assistance. Microentrepreneurs and vendors within the IMC can also take advantage of the IMF Business Model as practiced by Amanah Ikhtiar Malaysia and Mydin (the local entrepreneur supplied materials to the AIM's recipients to make clothing \& help to sell the clothing when 
completed).

In order for the IMC members to have saving and investment opportunities, IMC Cooperative will be set up. It is a savings and credit/investment cooperative implementing a profit and loss sharing approach. It is a community-based institution that operates under the cooperative system based on NGO domain. The main source of funds for the cooperative will be from the deposits put up by its clients in terms of savings and members of the cooperatives, plus a certain percentage of IMC' annual profits. Among the activities to be conducted by the cooperative includes property investments, Takaful cooperatives, and business development programmes. Under the business development programme, IMC may introduce various business development assistance programmes to its clients, such as marketing and financing assistance similar to the IMF Business Model. In this programme, microfinance recipients would be assisted in identifying potential buyers for their products, suggestions to open up new markets, and strategies on how to reduce various costs. The cooperative may also invest in technology and the training and development of its employees. It serves to ensure that the clients receive a smooth delivery of the best available technology in the microfinance market, such as the introduction of mobile banking and debit cards for IMC's members. By having a sustainable (self-dependent and self-sufficient) cooperative, it will provide potential IMC clients, current recipients, potential entrepreneurs, individuals interested in microfinance and experienced business tycoons to establish contact, share ideas, and thereafter become involved with projects that could give mutual benefit to all parties in the community. They can meet, discuss and exchange ideas with IMC experts to further improve their business projects and improve other entrepreneurial skills.

The pool of funds contributed by members together with the Waqf funds will eventually, in the long term, be invested to establish amenities/facilities such as schools and hospitals that can benefit the members of IMC and the general public. The big pool of funds will also assist in minimizing the operational and financial sustainability issues of the MFIs. Over time, as the IMC grows, the accumulated savings and profits can be recycled into new loans. The target is to promote the members in the community to be involved in business/investment with the hope that in future it can alleviate their standard of living. In other words the mission of IMC is to help the enterprising members in the community and to empower them economically, socially and spiritually.

Suggested strategies in the establishment of the Islamic Microfinance Community include a strong drive for membership and sources of fund, Islamic Product Innovation, improvement in Technology, and Education, Spiritual Development and Financial Literacy.

\subsection{Membership and Sources of Fund}

As shown in Figure 1, membership of IMC is opened to 4 different groups; namely microfinance recipients, general public, fund providers and non-financial institutions. The first group, the recipients include the present microfinance participants, the 'asnaf' that have been identified by Zakat authorities as well as potential entrepreneurs or prospective clients who are interested to obtain financing to start a business. The general public are entrepreneur graduates identified by Malaysian Academy of SME and Entrepreneurs Development (MASMED) or individuals interested in microfinance activities and would like to get involved with the projects, sharing knowledge, experience and expertise.

The lack of funds, as mentioned earlier, is the primary reason for the inability of Islamic Microfinance Institutions to be self-reliant. Hence, the fund providers or associate members can come from various sources: government, financial institutions or the current microfinance institutions. The integration of Islamic banks, financial institutions and MFIs, apart from benefit of scale, can also provide sources of funding. In addition it is important to capitalise funds from religious institutions such as zakat, waqf and other forms of charitable institutions, corporations, financial institutions, government agencies, foundations or even high net worth individuals who are interested in philanthropic activities. For example under the Wakalah-Waqf model, IMC will act as an agent and be paid a management fee for their work in managing the funds. The third source of funds includes the repayments by clients of loans that are recycled back into the community.

Further, Takaful operators are expected to give the recipients greater access to their financial services. IMC are also encouraged to include reserves within their operation due to high transaction costs to lend multitude loans of small amount of money to multitude borrowers, high-risk borrowers, and low return investments. These reserves can be used to cover some of the losses arising from borrower default. Therefore, as reserves increase, the IMC can utilise a higher proportion of its funds for microfinancing. Finally non-financial institutions such as agencies like AIM, TEKUN, Accounting Research Institute (ARI), MESMED, FAMA, FELDA, FELCRA will contribute their experience, knowledge, expertise, training and advisory services. It is hoped that members from various backgrounds with special skills and expertise will create a synergy to benefit each other. 
By having a community that are inclusive of Islamic microfinance providers; current recipients; participating merchants; zakat and waqf institutions and utilities provider etc., the recipients will be encouraged towards being financially stable to support themselves and their families. The IMC initiative where capital assistance is provided by the Islamic microfinance providers will be successful when the recipients can rise above the adequacy rate of the minimum basic needs (kifayah limit). This success will subsequently take the recipients out of poverty and become a zakat payer in future. Eventually every member in the Islamic microfinance community should be able to deposit a small amount of money to participate and become shareholders of the microfinance institution. Also, with better interaction between members of the community, benefits of establishing this community would be expanded to include other services, rather than acting as capital provider alone. Types of services that could be extended for recipients include savings insurance, health care and also personal development (Dewey, 2008).

\subsection{Islamic Product Innovation}

Other than the issue of sustainability of Islamic microfinance institutions, critics had also expressed their concern towards the authenticity of the Islamic financial products that these institutions offer. Many of the practitioners were seen to have added and rebranded products of conventional microfinance, not devising new business models to suit the purposes of Islamic microfinance. They argued that some products that are being offered as Shariah-compliant, for example cost-plus-mark-up Murabahah (allows customer to purchase fixed assets at a marked-up price on deferred payment basis) are being priced higher, similar to the pricing of conventional products with similar methodology (Khaled, 2011). This over-pricing is disguised as a cost marked-up or profit rather than to declare it as interest. But providing these or similar products to poorer clients, especially those who lack collateral, is a costly and risky endeavour.

As discussed above, IMC is not charity based but a business organisation aiming to achieve the goal of its members. However, if this goal of material accumulation causes harm to the member of society, then, it deviates from its objectives and fails the very essence of an Islamic financial institution, which is based on justice and benevolence. Islam stresses both the source and manner in which acquired wealth is spent (Attia, 2010). It has been reported that the Prophet (pbuh) said "On the Day of Resurrection, no human being will be released from God's presence until he has been asked where he obtained his material wealth and how he put it to use". Hence, material wealth has a significant social function and is not an end in itself, any attempt to hoard it, thereby keeping it out of circulation is a deviation from Maqasid Shariah (objective of the sharia) (Attia, 2010, p. 215).

Within IMC, the collaboration between Islamic Microfinance Institutions' partners and Institutions of Higher Learning (ARI for example) can improve Islamic Microfinance products to reduce transaction costs rather than passed them onto clients. Currently ARI has a research team working closely with AIM and Agro Bank to innovate Islamic Microfinance products specifically for agricultural and non-agricultural loans.

Partnership modes of financing are best suited for Muslim communities and it enhances productivity and wealth sharing in the society. It links the capital owner with the user in a cooperative way and developmental manner. Islamic microfinance could work with other networks such as retailers and wholesalers in a cooperative manner to achieve business success of micro-entrepreneurs. According to Bank Negara Malaysia (2012), Ijarah could be used to finance micro and small businesses where the use of machinery is needed in their operations; Mudaraba could be used for medium scale enterprises where the bank supplies the capital and the entrepreneur operates the business. For the microenterprises it is appropriate to use Murabaha. Salam, which is longer term, could be applied to finance agriculture sector so as to avoid mismatch between loan supply and its demand. It is interesting to note that about $60 \%$ of the purpose of financing micro-entrepreneurs is either due to working capital requirement or for purchase of machine/equipment (almost 30\% each). Only 9.4\% goes to project financing and about $18 \%$ for extension/renovations. In addition, the data shows that working capital is the main purpose of financing for $34 \%$ of micro enterprises.

This has implications for the allocations of funds to microenterprises using Islamic Micro-Investment Model (IMIM) as the model of financing. For instance, in terms of the skills acquisition at the first stage of the model, the waqf funds will provide funds for training according to the needs of the industry. In terms of the financing, the giving of cash to micro entrepreneurs may be risky at the start, especially when collaterals are not considered. The arrangement is therefore to make the parties work as partners rather than lenders and borrowers as in the current conventional practice. Partnership can be on the basis of profit sharing or output sharing. 


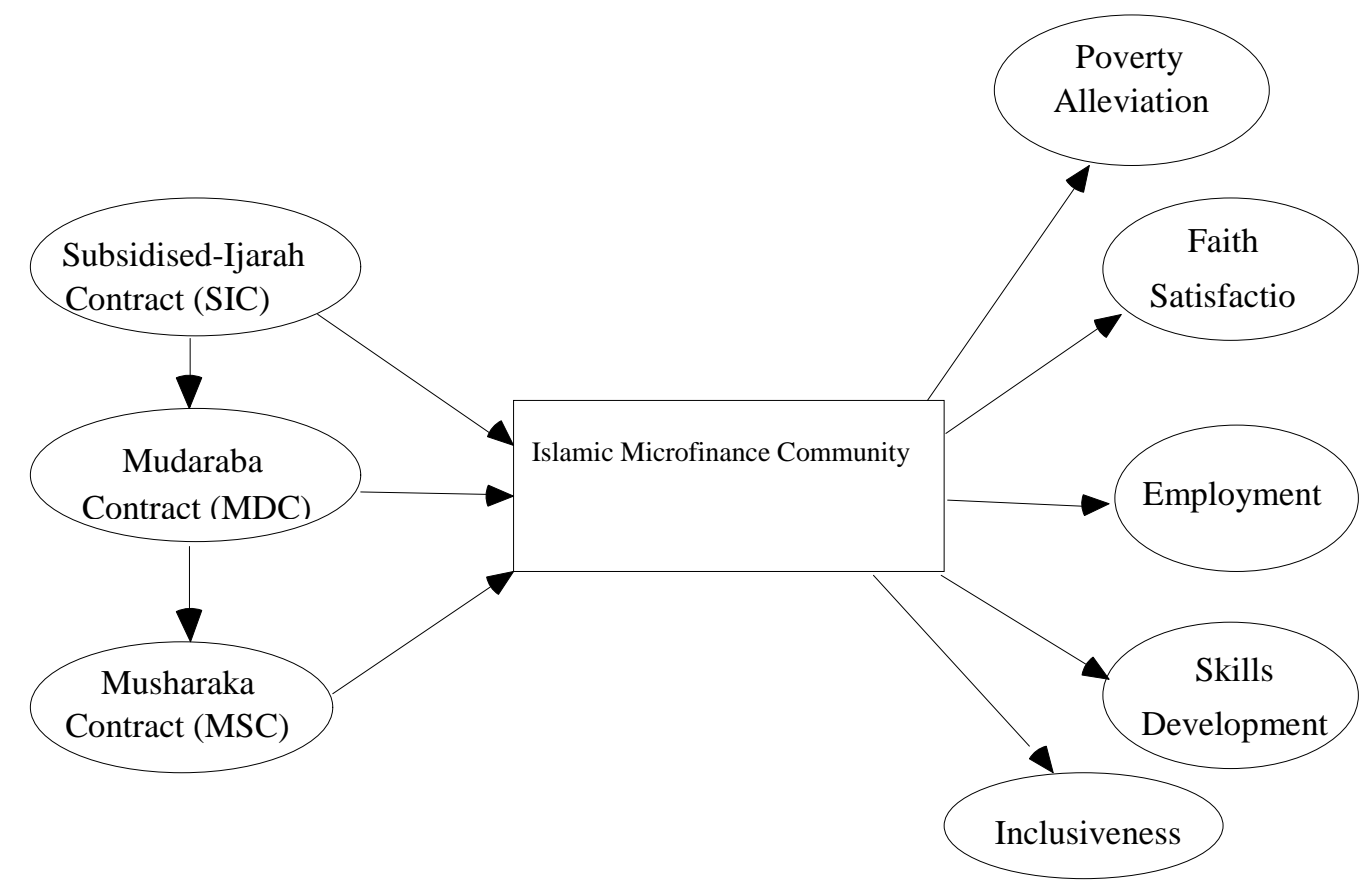

Figure 2. Islamic micro-investment model

Source: Abdul Rahman, Muhammad and Mahayudin (2013).

Abdul Rahman, Muhammad and Mahayudin (2013) introduced the Islamic Micro-Investment Model (IMIM) to be adopted by the Islamic Microfinance Community. Figure 2 depicts the 3 -stage model developed from the combinations of different contracts. These contracts, subsidized-Ijarah Contract (SIC), Mudaraba Contract (MDC) and Musharaka Contract (MSC) serve as building blocks of the model. SIC is the first stage whereby the entrepreneur who needs skills could join the programme and be trained using waqf or other philanthropic funds. Thereafter the client would be provided with the machine needed financed under leasing/ijarah. In MDC, the client may require only capital but he/she has the necessary skills for undertaking the business. The client will also be screened to reduce the problem of adverse selection. MSC entails partnership in providing capital for the proposed business. A client that passes through these stages has certainly acquired skills and capital and can undertake projects/business to reduce his level of poverty.

Islamic Microfinance Community (IMC) will offer subsidized services to the entrepreneurs by providing training free of charge as part of the institution's social responsibility. The micro-entrepreneur that graduates from the first stage can then join the Mudarabastage as he/she has possessed some skills for managing capital. The successful entrepreneur can be screened and if found suitable, he/she can be eligible for the second or third stage. IMC can then apply the various contracts applicable to the micro-entrepreneur as proposed under the IMIM. A recipient can join from the first stage. However, this may not be necessary as some recipients may not need ijarah contract.

The output of the model implementation is expected to significantly impact the income of the poor; provide fair and satisfactory returns to investors, operators and recipients. Additionally, employment, skills development and enhancement as well as inclusiveness are expected to be realized.

Shariah experts would be needed to facilitate product development. This is another issue at stake. However, IMC can solve the costly problem of instituting Shariah Supervisory Board (SSB) for each IMF institutions. Besides getting services from the SSB at Bank Negara Malaysia, an alternative is to set up SSB at IMC by pooling resources from a network of Islamic MF institutions locally and around the world and by forming an association at IMC, which could then set up a joint SSB. The divergence of fiqh can be addressed through this association and later tabled to the SSB at Bank Negara.

\subsection{Technology}

Besides savings and Takaful, there is also a need to include money transfer to the line of microfinance services in IMC. This is achievable, more so with the advancement of technology that is highly rapid today. The ease of 
reaching microentrepreneurs through their mobiles, sending and receiving bills and payments as well as reminders at a very low cost have the potential to reduce the costs of microfinance transaction dramatically. Mishra and Chowbwy (2009) and Nyokabi (2012) found that the adoption of technology in microfinance had encouraged an increment in their returns of funds and productivity of employees through the provision of secure, low cost and reliable means of transactional data capture and successful transfer to these institutions.

Microfinance institutions can have a partnership with technology providers in a cost-effective method. In some countries where regulation permits, telephone providers have been able to directly offer payment services through local agents to anyone who has a mobile phone but may not yet have a bank account. In Japan, Egypt and Nordic countries, mobile phones are being used in their mobile (M)-commerce application, where the clients' phones are linked to credit cards, debit cards or bank cards to make payments, while offering consumer protection, dispute resolution, anti-money laundering and IT security. Examples include "Egypt's Vodafone Cash, offered with HSBC, Mobicash in Morocco by Maroc Telecom with Attijariwafa Bank and Banque Central Populaire, and Mobile Money in Yemen, offered by MTN with the cooperative Agricultural Credit Bank" (Akhtar \& Pearce, 2010). M-PESA which is a mobile-based money transfer system with branchless banking that allows users to deposit, withdraw or transfer money using phones has revolutionised banking for the poor in Kenya.

One of the advantages of using mobile phone and debit card is that this type of electronic banking offers enhanced security and convenience while requiring minimal and inexpensive infrastructure. Mobile banking such as E-wallet or debit cards can serve the needs of micro-entrepreneurs for loan repayment and disbursement; voluntary savings deposit and withdrawals, fun transfers, remittance and takaful services, recharge airtime, pay bills, and financial education. The mobile phone and debit card could also serve as a mechanism to obtain discounts in purchasing business-related items from other vendors that are members of IMC. Hence, IMC can pioneer the use of electronic and mobile banking to deliver its services as well as a range of products.

\subsection{Education, Spiritual Development and Financial Literacy}

Another challenge in easing access to financial assistance for the underprivileged is improving education, spiritual development and financial literacy of the poor themselves. Using data from four dimensions (convenient accessibility, take-up rate, responsible usage and satisfaction) of Malaysia, a study by Bank Negara Malaysia on key performance indicators shows that a low-income group (segment of the population that earn less than RM1,000 per month) scored a lower index (0.68) compared to the general public of 0.77 (Abdul Rahman, 2013). The results indicate that there is a gap between the low-income segment and the general population, most probably due to varied level of financial awareness and knowledge between the two groups.

The keys to building a sustainable microfinance operation are time and commitment, thus IMC needs dedicated and competent managers supported by well-trained and motivated staff. The employees need to be well trained in banking, finance, investment, product awareness, entrepreneurship development and community development to enable them to impart their knowledge to the community effectively. There is also a need to train IMC recipients in subjects like basic accounting, due to the unavoidable fact that they calculate profits in participatory financing methods such as, mudarabah and musharakah. Working with other agencies within the community, IMC can work to increase recipients' financial knowledge and access to financial services by improving their level of financial literacy through financial counselling, debt management services and financial education. Additionally, business strategy training by these agencies can help the microfinance recipients to improve their entrepreneurship skills in maximising profits. Training should also be given to the microfinance staff to increase employees' productivity that would lead to reducing costs, and, simultaneously reduces the default rate that would increase revenues.

In the Islamic perspective of financial inclusion, the spiritual development, especially via internalizing Islamic moral values in the consciousness of entrepreneurs, is also necessary. Since poverty, as well as the economic issue has a moral, social and political dimension, it is aimed to develop honesty, discipline, spirit, diligence, patience, piety, social responsibility, to arouse awareness - changing the bad to good behaviour.

\section{Conclusion and Moving Forward}

Microfinance has evolved from providing microcredit to being about building an inclusive financial system that includes a wide range of financial products such as microsavings, microtakaful, and money transfer via mobile banking. However, there are cases around the world (example the financial inclusion in India) that are often closely connected to the aggressive micro credit policies which were introduced without the appropriate regulations oversight or consumer education policies. The result was consumers becoming quickly over-indebted to the point of committing suicide. Lending Institutions saw repayment rates collapse after politicians in one of 
the country's largest states called on borrowers to stop paying back their loans, threatening the existence of the entire 4 billion rupee a year Indian microcredit industry (Polgreen, 2010). Hence, the challenge for those working in the financial inclusion field has been to separate micro-credit as only one aspect of the larger financial inclusion efforts and use the Indian crisis as an example of the importance of having the appropriate regulatory and educational policy framework in place.

Further, the literature review reveals that Islamic MF Institutions have not yet tapped some of the sources of funds, nor have they used the variety of financial instruments and technology in their operations. Concerted efforts by all stakeholders are needed to make financial inclusion more meaningful and effective. Thus, IMC could be a one-stop centre. All members shall jointly contribute their experience, knowledge, expertise to ease the entire process of increasing the number of successful entrepreneurs in Malaysia. For example, if eligible, members could apply to join training programmes provided by MASMED; whilst financial advices and financial assistance could be given by AIM and Accounting Research Institutions (ARI); other interested parties could also offer other advisory services. The IMF Business Model that is currently practiced by AIM and Mydin Sdn Bhdcan be expanded and extended to the members within IMC.

Financial inclusion among the community would help to break the vicious cycle of poverty and help to uplift the standards of living of the poor. Within the Islamic Microfinance Community, the ideology of MaqasidShariah is justified through several principles of vertical ethicality where the creatures of God are to be treated equally (tauhid); horizontal ethicality in terms of social justice and beneficence (adalah and ihsan); growth in harmony (tazkiyah); allowing social and natural environment to reach and sustain its perfection (rububiyah); voluntary and compulsory action (fard) in serving social interest; also the responsibility of individuals to fulfil and act according to the preceding principles in their economic and financial behaviour as being the vicegerent of God on Earth (khalifah). As poverty itself is in conflict with the enrichment of self (nafs), which is one of the primary essences of MaqasidShariah (Obaidullah, 2008), trading and transactions among members of the Islamic Microfinance Community would help to enhance greater justice in the development process of self-enrichment, promoting further expansion of employment and self-employment opportunities, and enriching one's spiritual self-being.

With that, there is a need to establish a proper Islamic microfinance community that would be better tailored for contexts employing Islamic principles rather than having only cosmetic changes to their operations and products to acquire the Islamic credential. IMC should be working towards triple bottom lines; social, spiritual well-being and financial sustainability. This aspiration highlights the need for collaboration between the existing Microfinance Institutions in Malaysia, Banks, Telcos, Government Agencies and other stakeholders (such as institutions of higher learning (e.g. ARI), Bank Negara Malaysia and Financial Service Providers). The financial system will promote justice when risks are shared between financier and entrepreneur and the system mobilises resources and make them available for the poor through expansion of opportunities for investments, generation of employment and production to fulfil basic needs thereby contributing towards reduction in inequalities in income and wealth.

\section{Acknowledgements}

The authors are grateful to Accounting Research Institute, Universiti Teknologi MARA, Malaysia for full financial support granted to this research project.

\section{References}

Abdul Rahman, A. R. (2007). Islamic microfinance: A missing component in Islamic banking. Kyoto Bulletin of Islamic Area Studies, (1-2), 38-53.

Abdul Rahman, Z. (2013). Financial inclusion in Malaysia: Developing a financial inclusion index that will help monitor the progress towards achieving inclusive growth. Asian Link, 12, 7-11.

Abdul Rahman, R., \& Dean, F. (2013). Challenges and solutions in Islamic microfinance development. Humanomics, 29(4), 293-306. http://dx.doi.org/10.1108/H-06-2012-0013

Abdul Rahman, R., Muhammad, A. D., \& Mahayudin, I. (2013). Applicability of Islamic Micro-Investment Model (IMIM) in Islamic Bank in Malaysia. World Applied Sciences Journal, 1818-2492.

Akhtar, S., \& Pearce, D. (2010). Microfinance in the Arab World: The challenge of financial inclusion. MENA knowledge and learning.

Asian Development Bank. (2013). Microfinance: Financial services for the poor. Retrieved 11 March, 2013 from http://www.adb.org/sectors/finance/microfinance 
Attia, G. (2010). Towards realization of the higher intents of Islamic law: Maqasid al-shariah: A Functional approach. The International Institute of Islamic Thought (IIIT), USA.

Bernama. (April 26th, 2012). Islamic microfinance represents opportunity to develop ethical and profitable products, says najib. $\quad$ Retrieved 13th May, 2013 from http://www.1malaysia.com.my/news_archive/islamic-microfinance-represents-opportunity-to-develop-ethic al-and-profitable-products-says-najib/

Bernama. (January 23, 2013). Bank rakyat's microcredit loan to make debut by March. Retrieved 19 July, 2013 from http://www.bernama.com/finance/news.php?id=242880

Dewey, B. (2008). One mission, myriad benefits from microfinance institutions. Microfinance Institution Reviews. $\quad$ Retrieved 16th $\quad$ May, 2013 from http://www.nuwireinvestor.com/articles/microfinance-institution-reviews-51486.aspx

Ferro, N. (June, 2005). Value trough diversity: Microfinance and Islamic finance and global banking. Paper presented at Fondazione Enrico Mattei, Milan. http://dx.doi.org/10.2139/ssrn.755447

Global Islamic Finance Report. (2012). An edbiz consulting production.

Goud, B. (2007). Islamic microfinance. Report, Institute of Halal Investing. Retrieved 13th May 2013 from http://instituteofhalalinvesting.org/content/IslamicMF.pdf

Grameen Foundation. (2013). Microfinance basics. Retrieved 11th March, 2013 from http://www.grameenfoundation.org/what-we-do/microfinance-basics

Karim, N., \& Khaled, M. (2011). Retrieved 13th May, 2013 from http://www.cgap.org/blog/taking-islamic-microfinance-scale

Karim, N., Tarazi, M., \& Reille, X. (2008). Islamic microfinance: An emerging market niche. Focus Note, Consultative Group to Assist the Poor. Retrieved 13th May, 2013 from http://www.cgap.org/publications/islamic-microfinance-emerging-market-niche

Khan, A. A. (2011). What role for Islamic finance in promoting development? Paper presented at the Institute of Social Studies, The Hague, Netherlands, 9th February, 2011.

Kulik, N., \& Molinari, P. (2004). Sustainable microfinance and technology. Report, Ford Motor Company

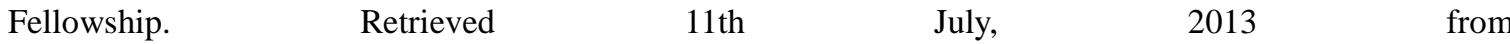
http://mackinstitute.wharton.upenn.edu/wp-content/uploads/2013/01/2003_2004__Kulik_Natalie_Molin ari_Patrice__Sustainable_Microfinance_and_Technology.pdf

MicroCapital.org. (September 24th, 2009). Exclusive interview on the current state of microfinance in malaysia and challenges facing the sector: Observations from the assistant governor of Bank Negara Malaysia. Retrieved 19th July, 2013 from http://www.microcapital.org/microcapitalorg-story-exclusive-interview-on-the-current-state-of-microfinanc e-in-malaysia-and-challenges-facing-the-sector-observations-from-the-assistant-governor-of-bank-negara-m alaysia/

Microcredit Summit. (2013). What is microfinance. Retrieved 11th March, 2013 from http://www.microcreditsummit.org/what-is-microfinance.html

Nyokabi, M. F. (2012). The role of information communication and technology in empowering local community through project implementation: A case of projects funded by Musoni Microfinance Kenya Ltd. Master's thesis, University of Nairobi.

Obaidullah, M. (2008). Introduction to Islamic microfinance. IBF Net (P) Limited, India.

Sait, M. S., \& Lim, H. (2005). Islamic credit and microfinance. In L. Islam (Ed.), Property research series. United Nations Human Settlements Programme (UN-HABITAT), Nairobi, Kenya.

\section{Copyrights}

Copyright for this article is retained by the author(s), with first publication rights granted to the journal.

This is an open-access article distributed under the terms and conditions of the Creative Commons Attribution license (http://creativecommons.org/licenses/by/3.0/). 